\title{
Thermal behaviour of edible crab Cancer pagurus Linnaeus, 1758 in
}

\section{coastal Norway}

\author{
Snorre Bakke, ${ }^{1,3}$, Sten I. Siikavuopio ${ }^{2}$ and Jorgen S. Christiansen, ${ }^{3,4}$
}

Bakke S, Siikavuopio SI and Christiansen JS. Thermal behaviour of edible crab Cancer pagurus Linnaeus, 1758 in coastal Norway. Fauna norvegica 39: 1-11.

Ocean warming drives latitudinal shifts in the distribution of ectotherm species. The rate and magnitude of such shifts are constrained by physiology and behavioural thermoregulation. Here, we investigated the thermal preference and lower critical temperature (CTmin) in female edible crab Cancer pagurus, a decapod crustacean with an ongoing northward dispersal along the Norwegian coast. The temperature selected by individual crabs from a northern (latitude $\sim 69^{\circ} \mathrm{N}$ ) and southern (latitude $\left.\sim 62^{\circ} \mathrm{N}\right)$ location was examined in a horizontal gradient $\left(5.5-14.5^{\circ} \mathrm{C}\right)$ under a simulated day and night light regime. Irrespective of origin, crabs showed pronounced responses to the light cycle - during the day crabs stayed inactive in the warm end of the gradient but during night they actively explored the entire gradient. A preferred temperature of $\sim 13{ }^{\circ} \mathrm{C}$ (measured as mode of loggings) was identified for crabs from both locations. Righting reflex experiments of crabs exposed to a rapid temperature drop (7 $-1{ }^{\circ} \mathrm{C}$ at $-0.1{ }^{\circ} \mathrm{C} / \mathrm{min}$ ) identified a CTmin of $\sim 1.3{ }^{\circ} \mathrm{C}$ (i.e., the temperature at which $50 \%$ of crabs failed to right from an up-side-down position), and with no significant difference between locations ( $p>0.05)$. Our results provide important information about the functional characteristics of edible crab, and are discussed in context of the biology and ongoing northward dispersal of the species.

doi: 10.5324/fn.v39i0.2738. Received: 2018-10-02. Accepted: 2019-01-24. Published online: 2019-02-26. ISSN: 1891-5396 (electronic).

Keywords: Cancer pagurus, Norway, latitude, thermal behaviour, lower critical temperature

\author{
1. Møreforsking Alesund AS, NO-6021 Alesund, Norway \\ 2. NOFIMA - The Norwegian Institute of Food, Fisheries and Aquaculture Research, NO-9291 Tromsø, \\ Norway \\ 3. Department of Arctic and Marine Biology, UiT - The Arctic University of Norway, NO-9037 Tromsø, \\ Norway \\ 4. Environmental and Marine Biology, Abo Akademi University, Turku, Finland
}

Corresponding author: Snorre Bakke

E-mail:snorre.bakke@moreforsk.no

\section{INTRODUCTION}

The edible crab (Cancer pagurus Linnaeus, 1758) is a subtidal decapod crustacean and an important fisheries resource across most of its distribution in the north-eastern Atlantic. Around 50 thousand metric tons are landed in Europe annually (FAO 2015), of which $\sim 5$ thousand are harvested by Norwegian fishers (Søvik et al. 2017). In the late 1970's Torheim (1977; 1979) suggested that the northern distribution border of the edible crab was just north of $68^{\circ} \mathrm{N}$, and reported that he only found a high enough density of crabs to sustain a fishery south of $\sim 67^{\circ} \mathrm{N}$.
Currently, the edible crab is harvested as far north as $69^{\circ} \mathrm{N}$ (Woll et al. 2006; Bakke et al. 2016), and have been observed in waters close to $71^{\circ} \mathrm{N}$ (Brattegard 2011). Due to rising ocean temperatures, such displacement and shifts in distribution are evident for much of the worlds marine biota (Perry et al. 2005; Poloczanska et al. 2013), and worries are raised regarding both the potential ecological and socio-economical consequences of these changes (Allison et al. 2009; Cheung et al. 2009; Cheung et al. 2010). To better understand how species respond to these environmental changes it is important to know their preference, 
tolerance, and ability to adapt to temperature.

The effect of ocean warming on physiological performance and thresholds has been studied extensively in marine ectotherms (see for instance Somero 2012; Pörtner and Gutt 2016; Pörtner et al. 2017). For benthic crustaceans, warming is especially considered critical for stenotherm animals, isolated intertidal populations, and for individuals residing at the warmer low latitude boundary of their realized habitat, where seasonal temperatures approach upper thermal performance limits (Stillman and Somero 2000; Kelly et al. 2012). Motivated by concern for the displacement or extinction of crustaceans from warming habitats, many studies have focused on the upper critical or Pejus (from good to bad) temperatures (see below). Several marine crustaceans however show a certain degree of eurythermy, and usually have a corresponding wider biogeographical distribution. For instance, the edible crab is exposed to a range of ambient temperatures across its geographic distribution, which stretches from northern Africa to beyond the Arctic Circle (FAO 2015). For individuals living at the highest latitudes, where low temperatures impose restrictions on metabolic processes, ocean warming and shifting isotherms might create a potential for better physiological performance and expansion of distribution boundaries.

This "border-of-opportunity" hypothesis however assumes that high latitude residents do not constitute a cold-adapted ecotype. The effect of temperature on geographically separated crustaceans has been investigated in several studies (Fox 1936; Fox and Wingfield 1937; Tashian 1956; Roberts 1957; Vernbergs and Vernberg 1966; Stillman and Somero 2000; Stillman 2003; Stillman 2004; Faulkner et al. 2014; Gaitán-Espitia et al. 2014; Cumillaf et al. 2016), and shows that both origin and local thermal conditions indeed affect physiological performance and tolerance. Most of these studies have however examined intertidal crustacean species (with highly variable thermal environments) or made comparison between closely related crustaceans (from the same genus or family), with a strong emphasis on upper thermal limits. Cuculescu et al. (1998) identified the upper thermal tolerance limits for the edible crab, and also found it to vary with season and acclimation temperature. However, whether thermal acclimatization exists across latitudes for the edible crab is not known, and we lack information regarding the species preference and tolerance to lower temperatures, i.e., similar to those experienced during winter and at the northern margin of its distribution.

As opposed to thermal limits, which are largely affected by acclimation temperature, it has been suggested that there is a species specific thermal preferendum, which Fry (1947) defined to be the "temperaturearound whichallindividuals willultimately congregate, regardless of their thermal experience" (if allowed to move freely in a heterothermic environment). The thermal preferendum is usually determined either by the "gravitational method", identified as the prevailing temperature selected by an animal held in a thermal gradient over time (typically 24-48 hours), or through the "acute method", identifying the more immediate thermal preference of individuals acclimated to different temperatures (Reynolds and Casterlin 1979), and where the thermal preferendum is considered the temperature were the acclimation temperature and the acute temperature preference of a species is the same (Fry 1947; Reynolds and Casterlin 1979). Some studies on fishes and crustacean have however suggested that the thermal preferendum might not be as stringent as previously believed, and that it for a given species may vary with ontogeny (McCauley and Huggins 1979; Lafrance et al. 2005), season (McCauley and Huggins 1979; Clark and Green 1991; Despatie et al. 2001; Reiser et al. 2016) and even personality traits (Sonia et al. 2015; Cerqueira et al. 2016). Thermal preferendum has also been found to vary between populations of coho salmon (Oncorhynchus kisutch) raised in the same environment (Konecki et al. 1995), however, studies on other juvenile fish have identified the same thermal preferendum for geographically separated populations (Wagner and Wahl 2007; Siikavuopio et al. 2014). On the other hand, the thermal preferendum within crustacean species originating from different thermal habitats remains to be investigated.

In this study we investigate the thermal behaviour and identify the thermal preference and the critical thermal minimum (CTmin) in female edible crab from two latitudes in coastal Norway.

\section{MATERIALS AND METHODS}

\section{Origin of animals and thermal history}

Live intact females of edible crab Cancer pagurus were sampled from the northern margin of the species distribution (i.e., Senja Island, Troms County, location: $\left.69^{\circ} 09.200 \mathrm{~N} / 16^{\circ} 50.590 \mathrm{E}\right)$, depth: $\sim 20 \mathrm{~m}$ and from a location about $900 \mathrm{~km}$ further south (i.e., Ålesund, Møre og Romsdal County, location: $62^{\circ} 28.556 \mathrm{~N} / 5^{\circ} 56.324 \mathrm{E}$, depth: $\sim 20 \mathrm{~m}$ (Figure 1).

To ensure a sufficient number of intact specimens when starting our winter experiments, about 30 crabs were sampled from each area at the end of the commercial fishing season (mid-November) in 2015, using baited pots in cooperation with local fishermen. Details on crabs and origin of catch are presented in Table 1. Only female crabs were tested because they are likely more affected by environmental temperature due to their complex reproductive cycle (Bennett 1995).

Corresponding temperature data (mean for years 20002015, depth: 0-200 m) in proximity to the respective catch sites were provided by the Institute of Marine Research (www.imr. no) (Table 2).

Crabs were transported to the laboratory in Ålesund (5 days refrigerated transport by boat and car for crabs from the north), where they were kept under a 12h/12h light/dark cycle (one hour ramp) in six 4001 fiberglass tanks containing rocks and artificial (plastic) kelp as shelter (OK Marine AS, Kristiansand, Norway). As the main aim of our study was to examine the thermal behaviour and tolerance in cold water, 
Table I. Female edible crab Cancer pagurus used in experiments. CW=Carapace width.

\begin{tabular}{llllll}
\hline Group & Location of catch & Date of catch & Mean size $(\mathrm{mm} \mathrm{CW} \pm$ s.d.) & N Experiment 1 & N Experiment 2 \\
\hline North & $69^{\circ} 09.200 \mathrm{~N} / 16^{\circ} 50.590 \mathrm{E}$ & 20.11 .2015 & $144 \pm 9$ & 6 & 8 \\
South & $62^{\circ} 28.556 \mathrm{~N} / 5^{\circ} 56.324 \mathrm{E}$ & 22.11 .2015 & $143 \pm 8$ & 6 & 8 \\
\hline
\end{tabular}

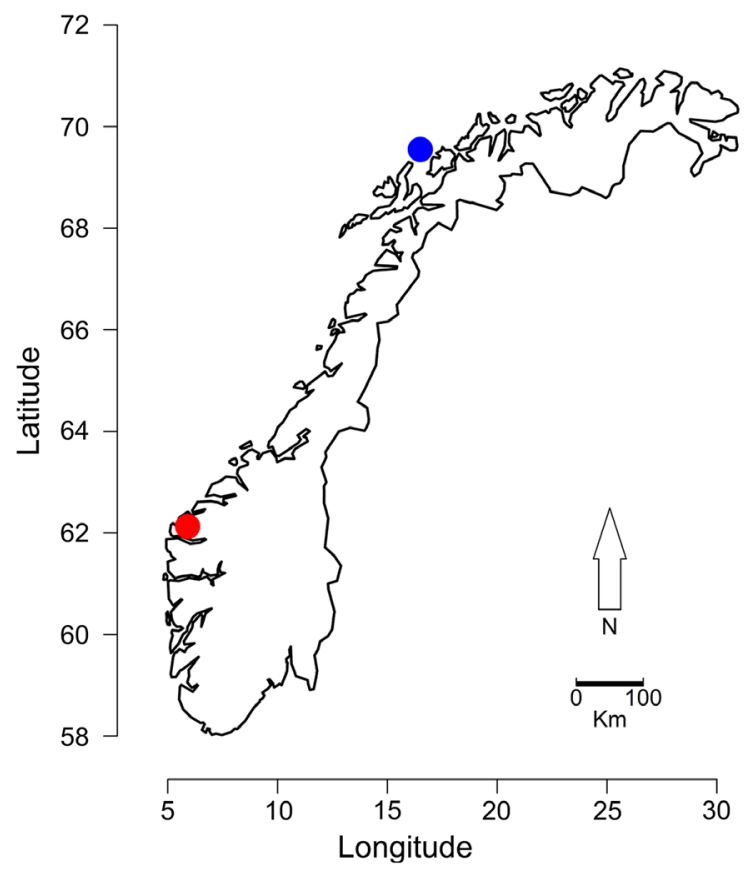

Figure I. Map of Norway showing origin of edible crab Cancer pagurus used in experiments; blue $=$ north and red $=$ south. Details presented in Table 1.

the crabs were held from mid November 2015 till end of March 2016, when seasonal water temperatures were expected to be at their annual low. Tanks were supplied with unfiltered seawater from 40 meters depth, and temperature declined gradually from $\sim 11^{\circ} \mathrm{C}$ (November) to $\sim 8^{\circ} \mathrm{C}$ (March), which was the holding temperature at the onset of experiments. During the holding period the crabs were fed in excess with pieces of fishes (saithe and herring) at least once a week.

\section{Experiment I - Thermal preference}

To study the thermal preference of crabs we employed the "gravitational method" (see Reynolds and Casterlin 1979) using the same approach as used for red king crab (Paralithodes camtschaticus) by Christiansen et al. (2015). A fiberglass tank consisting of two separate and parallel channels (260x90x30 $\mathrm{cm}$ ), each with water volume of $\sim 500$ 1, was used (Figure 2). Water inlets at four cells along the channels were connected to a cold and warm circuit, allowing mixing of water and reversing the temperature gradient. The gradient in each channel spanned $9^{\circ} \mathrm{C}$ from $\sim 5.5$ to $\sim 14.5^{\circ} \mathrm{C}$. There was a temperature difference of about $2{ }^{\circ} \mathrm{C}$ between cells. To ensure that the observed behaviour was solely driven by ambient temperature, no shelter or sediments were used, and the gradient in the two channels

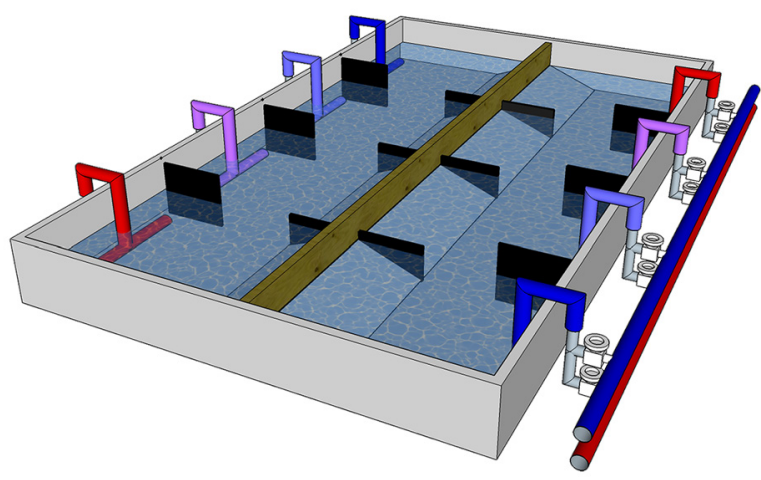

Figure 2. Raceway system with two thermal gradients. Temperature gradients were obtained by mixing cold (blue) and warm (red) water on four inlets along the channel. Ball plug valve at each point and temperature allowed fine tuning of temperature and reversal of the thermal gradient. Flow-meters attached to each inlet point allowed accurate mixing of volumes of water (not shown in figure).

was run in opposite direction which was reversed after every second test.

As juvenile and mature crabs occupy different habitats and show different seasonal behaviour (Bennett 1995; Robinson and Tully 2000) only crabs of about $140 \mathrm{~mm}$ carapace width (CW) were used, i.e., well above body size at physiological maturity (Haig et al. 2016; Bakke et al. 2018). Two days prior to tests, a single crab from each location was taken from the holding tank and fitted with a temperature logger dorsally on the carapace (IBcod type Z, Alpha Mach, Quebec, Canada) before being left undisturbed and unfed in a separate tank at the holding temperature $8^{\circ} \mathrm{C}$. The temperature logger was set to register temperature every second minute. During the two-week experimental period (March), a total of twelve unfed crabs were tested once ( $\mathrm{n}=6$ from each location) and single individuals were allowed to move undisturbed in the thermal gradient for a period of $\sim 40$ hours, maintaining the same light/ dark cycle as during holding (onset of light at $06.00 \mathrm{~h}$ and onset of darkness at $18.00 \mathrm{~h}$ (one hour ramp)). Single crabs were exposed to the gradient between 12:00 $\mathrm{h}$ and 16:00 h (light hours). The behaviour may be affected by the temperature of release (Lewis and Ayers 2014), therefore, crabs were released into a gradient temperature similar to that of the holding tank $\left(\sim 8^{\circ} \mathrm{C}\right)$. To simplify comparisons and to reduce putative effects of handling, the onset of first night (18:00 h) was used as a starting point for data analyses. Onset of daylight on the second day (08:00 h) was set as endpoint of data analyses, yielding 1140 data loggings for each individual. For each crab, the mode of all temperature loggings (nearest $0.5^{\circ} \mathrm{C}$ ) was used as a measure of 
preferred temperature (Haro 1991), i.e., the $0.5^{\circ} \mathrm{C}$ temperature interval with most temperature loggings. Modes rather than means were used because individual variability in activity within the thermal gradient would strongly influence the standard deviation of mean values. The modes were averaged among crabs from the two locations, and the difference in preferred temperature between groups was tested with a Welch's T-test.

It appeared that northern crabs spent more time at lower temperatures during night. To test this, the mean proportion of temperature loggings ( $n=5$ crabs per location) being below the median temperature of the gradient $\left(10^{\circ} \mathrm{C}\right)$ was compared between the two groups using a Student's T-test. A ShapiroWilks test was used for test of normality, and equality of variances tested by an F-test

To investigate the crabs' ability to move across gradient temperatures the five largest temperature changes between two consecutive temperature loggings were extracted for each individual (five changes towards a higher and five changes towards a lower temperature). Care was taken not to include data from the same run/thermal movement, i.e., loggings that were closer than one hour in time were excluded. The rate of temperature change registered by single crabs in the gradient (proxy for movement) was modelled as a function of the interaction between origin (north or south) and direction of movement (towards high or towards low temperatures), and as a function of carapace width. A generalized linear mixed-effects model was used, with Crab ID included as a random effect. Except for one value from a northern crab (migration during early morning), all the largest changes between two consecutive loggings were found during night-time. Time of day was therefore not included as a factor in the model.

\section{Experiment 2 - Righting reflexes at decreasing temperature}

In April 2016, eight additional crabs from each location were transferred from the holding tank to a separate tank at $\sim 7^{\circ} \mathrm{C}$ for two days without food. During tests, the crabs were held individually in $30 \times 30 \mathrm{~cm}$ chambers in a tank provided with recycled refrigerated seawater (Adriatic Sea International, Rome, Italy) and with a perforated grid on the bottom to give foothold. The critical minimum temperature (CTmin) was inferred from the ability of crabs to turn from an up-side-down position back into an upright position (i.e., the righting reflex) at given temperatures (Lagerspetz and Bowler 1993). Before onset of tests, the crabs were kept in darkness at $7.0^{\circ} \mathrm{C}$ for 15 minutes in an up-right position. The temperature was lowered from 7.0 to $1.0^{\circ} \mathrm{C}$ at a constant rate of $\sim-0.1^{\circ} \mathrm{C} / \mathrm{min}$. At every temperature reduction of $0.5^{\circ} \mathrm{C}$, i.e., at $5 \mathrm{~min}$ intervals, the crabs were turned up-side-down and left undisturbed for two minutes and then inspected. If crabs did not return to the upright position, the observation was registered as a failed righting reflex. Crabs were then manually turned upright before next inspection 3 minutes later. The probability of righting reflexes was modelled with a generalized linear model (GLM) with the binary response $(1=$ up-side-down position maintained, $0=$ upright position achieved) as a function of the interaction between temperature and location (north or south). The CTmin was considered the modelled temperature at which $50 \%$ of the crabs failed to show righting reflex. After the experiment, crabs were returned to the holding tanks (i.e., from 1.0 to $7^{\circ} \mathrm{C}$ ).

Statistical analyses and graphical illustrations were made in R Version 3.3.1 (R Core Team 2016), except for Figure 2 which was made in SketchUp (Trimble, CA, USA).

\section{RESULTS}

The seasonal temperatures at the two sampling sites are shown in Table 2. Overall the southern location was around $1^{\circ} \mathrm{C}$ warmer than the northern, but with more pronounced differences during late summer and autumn (shallow water $(<50$ $\mathrm{m})$ was on average $2-3^{\circ} \mathrm{C}$ warmer in the south). Assumptions are made that bottom temperatures at sampling sites were similar to the temperatures measured at the corresponding depth of the water column.

\section{Experiment I - Thermal preference}

The temperature loggings by 10 individual crabs are shown in Figure 3. (Data from two crabs were omitted - one animal (North) lost the logger and one immotile animal (South) had started to spawn.) The estimated mean preference temperature (mode of loggings) was similar for crabs at both locations i.e., $12.9( \pm 0.4)^{\circ} \mathrm{C}$ (North) and $13.0( \pm 1.6)^{\circ} \mathrm{C}$ (South) (Table 3).

The proportion of individual crab loggings at different temperature intervals was plotted for the three consecutive periods: first night, daytime and second night (Figure 4). During both nights the temperature loggings showed that the crabs utilized the entire thermal gradient. During daytime, on the other hand, little movement was registered, with crabs from both locations consistently lying quiescent in the warmer end of the gradient. When comparing crabs from the two locations in terms of proportion of loggings made below or above the median temperature of the gradient (i.e, $10^{\circ} \mathrm{C}$ ), separate tests for first and second night showed no significant difference. However, night-time data overall showed a significantly higher proportion of cold water loggings by crabs from the north $(\sim 30 \%$ of nightly observations $\left.<10^{\circ} \mathrm{C}\right)$ compared to crabs from the south $(\sim 10 \%$ of nightly observations $\left.<10^{\circ} \mathrm{C}\right)(\mathrm{p}=0.04, \mathrm{df}=8)$.

Analysis of the rate of movement and subsequent temperature shifts within the gradient showed no effect of origin, direction of movement, or carapace width. The interaction term (origin $x$ direction of movement) was however significant $(\mathrm{p}=0.04, \mathrm{df}=$ 88), with Tukey's simultaneous tests indicating a higher rate of movement towards warmer waters for southern crabs compared to crabs from the north (Table 3).

\section{Experiment 2 - Righting reflexes at decreasing temperature}

Results from the righting reflex experiment showed a tendency 
Table 2. Temperature at depths in proximity to sampling sites of female edible crab Cancer pagurus.

\begin{tabular}{lcccccccccccc}
\hline Location/Depth & Jan & Feb & Mar & Apr & May & Jun & Jul & Aug & Sep & Oct & Nov & Dec \\
\hline North* & & & & & & & & & & & & \\
$5-10 \mathrm{~m}$ & 5.9 & 5.0 & 4.6 & 5.0 & 6.5 & $\mathbf{8 . 7}$ & $\mathbf{1 0 . 9}$ & $\mathbf{1 1 . 5}$ & $\mathbf{1 1 . 0}$ & $\mathbf{1 0 . 0}$ & 8.7 & 7.3 \\
$10-50 \mathrm{~m}$ & 6.1 & 5.3 & 4.9 & 5.1 & 6.2 & 7.6 & 8.8 & 9.4 & 10.2 & $\mathbf{1 0 . 1}$ & 8.8 & 7.4 \\
$50-100 \mathrm{~m}$ & 6.7 & 5.9 & 5.5 & 5.5 & 6.1 & 6.8 & 7.3 & 7.6 & 8.3 & 9.6 & $\mathbf{9 . 0}$ & 7.9 \\
$100-200 \mathrm{~m}$ & $\mathbf{7 . 7}$ & $\mathbf{7 . 1}$ & $\mathbf{6 . 6}$ & $\mathbf{6 . 5}$ & $\mathbf{6 . 7}$ & 7.1 & 7.3 & 7.5 & 7.6 & 8.0 & 8.4 & $\mathbf{8 . 4}$ \\
South* & & & & & & & & & & & & \\
$5-10 \mathrm{~m}$ & 6.5 & 5.7 & 5.5 & 5.9 & 7.7 & $\mathbf{1 0 . 0}$ & $\mathbf{1 2 . 3}$ & $\mathbf{1 4 . 1}$ & $\mathbf{1 4 . 2}$ & 11.8 & 9.7 & 7.9 \\
$10-50 \mathrm{~m}$ & 6.9 & 6.2 & 5.7 & 5.8 & 7.0 & 8.3 & 9.3 & 11.5 & 12.9 & $\mathbf{1 2 . 1}$ & $\mathbf{1 0 . 2}$ & 8.5 \\
$50-100 \mathrm{~m}$ & 8.0 & 7.0 & 6.5 & 6.6 & 7.1 & 7.7 & 7.9 & 8.2 & 8.7 & 10.2 & 10.1 & $\mathbf{9 . 4}$ \\
$100-200 \mathrm{~m}$ & $\mathbf{9 . 0}$ & $\mathbf{8 . 0}$ & $\mathbf{7 . 6}$ & $\mathbf{7 . 6}$ & $\mathbf{7 . 8}$ & 8.1 & 8.1 & 8.0 & 8.2 & 8.6 & 9.2 & 9.3 \\
& & & & & & & & & & & & \\
Difference South-North & & & & & & & & & & & & \\
$5-10 \mathrm{~m}$ & 0.6 & 0.7 & 0.8 & 0.9 & 1.3 & 1.3 & 1.4 & 2.6 & 3.2 & 1.8 & 1.0 & 0.6 \\
$10-50 \mathrm{~m}$ & 0.7 & 0.9 & 0.8 & 0.7 & 0.8 & 0.7 & 0.5 & 2.1 & 2.7 & 2.0 & 1.4 & 1.0 \\
$50-100 \mathrm{~m}$ & 1.3 & 1.0 & 1.1 & 1.1 & 1.0 & 1.0 & 0.6 & 0.6 & 0.4 & 0.6 & 1.1 & 1.5 \\
$100-200 \mathrm{~m}$ & 1.3 & 0.9 & 1.0 & 1.1 & 1.1 & 1.0 & 0.8 & 0.5 & 0.6 & 0.6 & 0.8 & 0.9 \\
\hline
\end{tabular}

* Temperature data were obtained from the hydrographical stations Eggum (North) and Bud (South), both operated by the Institute of Marine Research. (Data are available online http://www.imr.no/forskning/forskningsdata/stasjoner/). Cells with light grey shading denote temperatures in proximity to preferred temperatures (see Results/Discussion). Cells with dark grey shading denote temperatures likely to be below lower Pejus (see Discussion). Depths with highest temperature are shown in bold.

Table 3. Summary results on thermal preference and movement for female edible crab Cancer pagurus.

\begin{tabular}{lccc}
\hline & & \multicolumn{2}{c}{$\begin{array}{c}\text { max Thermal movement } \\
\left(\left|\Delta^{\circ} \mathrm{C}\right| / \mathrm{min} \pm \text { s.d. }\right)\end{array}$} \\
Group & $\begin{array}{c}\mathrm{MTP}^{1} \\
\left({ }^{\circ} \mathrm{C} \pm \text { s.d. }\right)\end{array}$ & Towards warm & Towards cold \\
\hline North & $12.9 \pm 0.4$ & $1.09 \pm 0.35^{\mathrm{a}}$ & $1.13 \pm 0.35^{\mathrm{a}}$ \\
South & $13.0 \pm 1.6$ & $1.49 \pm 0.27^{\mathrm{b}}$ & $1.31 \pm 0.29^{\mathrm{ab}}$ \\
Overall & $13.0 \pm 1.1$ & $1.22 \pm 0.33$ & $1.29 \pm 0.35$ \\
\hline
\end{tabular}

1. Mean Temperature Preference. Averaged from the mode of temperature loggings for each crab. ${ }^{2}$. Rate of movement in the thermal gradient. Different superscript letters denote significant differences at the $5 \%$ level.

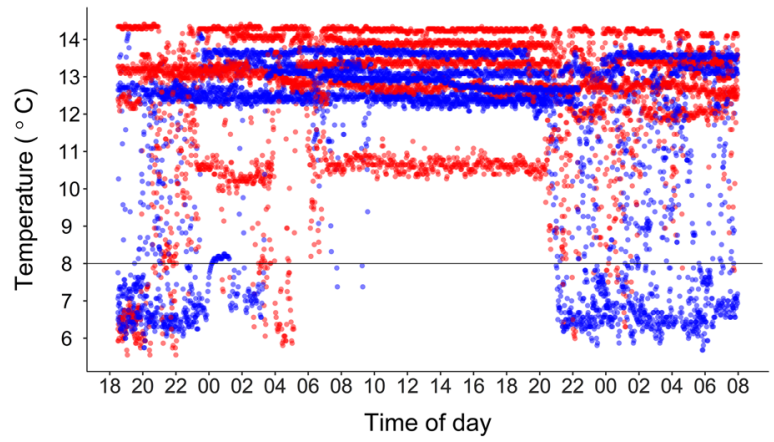

Figure 3. Movement of individual edible crab Cancer pagurus in a thermal horizontal gradient. Blue dots show crabs originating from north $(\mathrm{n}=5)$ and red dots crabs from south $(\mathrm{n}=5)$. Horizontal line denotes acclimation (and introduction) temperature at onset of tests. towards a lower CTmin for northern crabs. However, when modelled, the effect of origin was not statistically significant ( $\mathrm{p}$ $=0.08$ ). Overall, $50 \%$ of the crabs lost their righting reflex at $1.28( \pm 0.68 \mathrm{SE})^{\circ} \mathrm{C}$. All crabs survived the experiment and the subsequent one-week holding period at $7^{\circ} \mathrm{C}$.

\section{DISCUSSION}

Reptant decapod crustaceans are well suited for thermobehavioural studies, as they can readily move and maintain preferred positions within thermal gradients (Crossin et al. 1998; Lewis and Ayers 2014; Christiansen et al. 2015; PadillaRamírez et al. 2015; Nielsen and McGaw 2016). This has also been demonstrated in our study where a clear thermal behaviour 


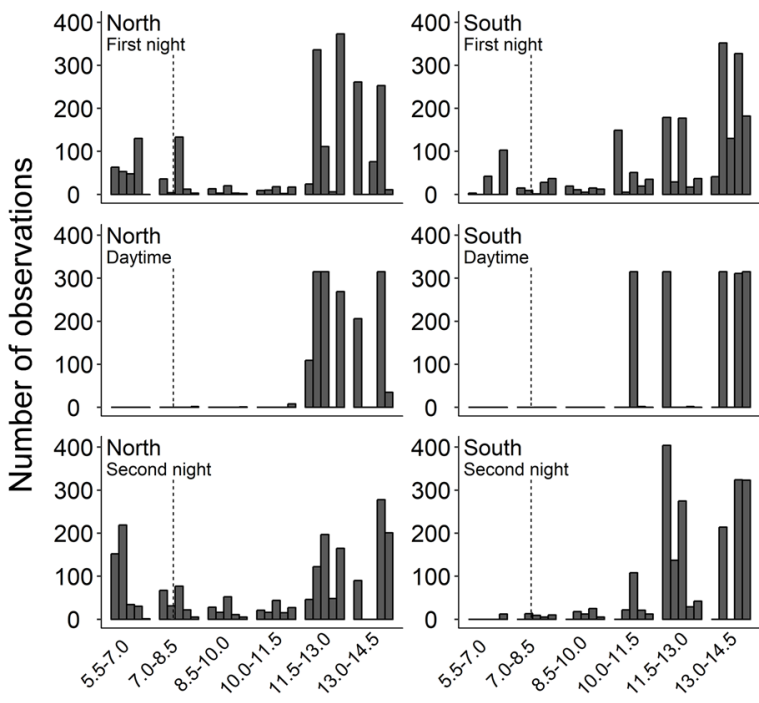

Selected temperature interval $\left({ }^{\circ} \mathrm{C}\right)$

Figure 4. Number of observations at different temperature intervals selected by individual edible crab Cancer pagurus during the $\sim 40$ hour period within the thermal gradient. One observation equals 2 minutes. Figure shows observations for first night (top), daytime (middle) and second night (bottom) for crabs from North (left) and South (right). For each location, the position of a bar within temperature intervals corresponds to the same individual. Vertical dotted line denotes acclimation (and introduction) temperature at the onset of tests.

is observed for female edible crab. When conducting gradient experiments it is important to reduce contact- or cornerseeking behaviour (Lagerspetz and Vainio 2006). Studies on the behaviour of edible crab have shown that it readily seeks shelter or burrows into the sediment (Bennett and Brown 1983; Lawton 1989; Skajaa et al. 1998). Our own observations, both in the holding tanks and in the thermal gradient, revealed that some crabs were attracted to the walls of the tank. Although the position of single crabs might result from positive thigmotaxis, the consistent selection of the high temperature areas strongly suggests that temperature was the main driving force in behaviour.

Under aerobic conditions, physiological processes in ectotherms are adapted to the "thermal window" between the upper and lower Pejus temperature (Lagerspetz and Vainio 2006; Pörtner et al. 2017), with preferred temperatures often corresponding to optimal performance for growth (Jobling 1981). But thermal preference does not necessarily match temperatures at optimal physiological performance for all life history processes (Angilletta et al. 2002). Studies on elasmobranchs, bony fishes and reptiles have for instance shown that gravid animals select higher temperatures during gestation (Christiansen et al. 1997; Angilletta 2009; Schlaff et al. 2014). Whether such optimization strategies exist for crustaceans are unclear and studies on (intertidal) crab species are inconsistent
(Kerr et al. 2012; Clark and Backwell 2016). March and April (the period of our experiments) is the season when ovigerous female edible crabs incubate their eggs (Williamson 1904; Meek 1914; Bennett and Brown 1983; Le Foll 1986; Woll 2003; Ungfors et al. 2007; Hunter et al. 2013). In the North Atlantic, edible crab do not necessarily spawn every year, but spawning success depends on time of mating, body size and nutritional gain after moulting and mating (Pearson 1908; Edwards 1979; Latrouite and Noël 1993; Ungfors 2007). Except for one spawning crab (not used in data analysis), none of the other test crabs were berried even by the end of May. Thus, crabs used in our experiments had either skipped spawning or had yet to build up energy reserves to spawn.

The mean preferred temperature did not differ across latitudes for adult female edible crab and revealed a final thermal preferendum of $13 \pm 1^{\circ} \mathrm{C}$ (Table 3). Our results are in line with studies on fishes (Wagner and Wahl 2007; Siikavuopio et al. 2014), and conform to the theory of a final thermal preferendum (Fry, 1947; Reynolds and Casterlin, 1979; Jobling, 1981).

On the other hand, whether variations in thermal preferendum exist throughout development or between seasons, such as demonstrated in brown shrimp (Crangon crangon) (Reiser et al. 2016), remains to be investigated. Further, physiological performance and life history traits may vary among geographically separated populations, and differences in some of these traits, including thermal tolerance, can be evident even after long periods at the same environmental condition (see Sanford and Kelly 2011). But the similar CTmin for edible crab from both locations suggests that putative differences in thermal behaviour had been eliminated during the 20 -week holding period. However, the tendency for northern crabs to spend more time in the low temperature range of the gradient (Figure 3 and Figure 4) warrants further investigations into potential physiological differences.

Irrespective of origin, our study shows that edible crab displays a high degree of eurythermy because it readily moves within the entire gradient ranging from $\sim 5.5$ to $\sim 14.5^{\circ} \mathrm{C}$ (Figure 3 and Figure 4). In nature, such flexibility is clearly most advantageous during spring and autumn when temperature gradients in the water column peak (see Table 2, and Karlsson and Christiansen 1996). It is well known that edible crab migrates to shallow inter-tidal water during summer where they feed on molluscs and barnacles, and sharp temperature changes may occur during foraging as shown from studies in southern Norway (Karlsson and Christiansen 1996). It is thus tempting to speculate that the observed tendency for southern crabs to move at a higher speed between temperatures (Table 3 ) is an adaptation to a more varying thermal environment. Our observation alone is however insufficient to make such conclusions, as the differences also could be related to subtle unidentified physiological differences between crabs at the two locations.

The edible crab is a nocturnal forager, with movements and 
metabolic activity being very much reduced during daytime (Ansell 1973; Aldrich 1975; Karlsson and Christiansen 1996; Skajaa et al. 1998; Scott et al. 2018). This is also supported by our results (Figure 3 and Figure 4) - at the onset of light, crabs consistently moved toward the warm end of the gradient where they stayed largely inactive during daytime. Field and laboratory investigations on fishes and crustaceans have shown that animals may leave the preferred temperature and salinity zones to forage under sub-optimal conditions (Sims et al. 2006; Curtis and McGaw 2012). Our findings may suggest a similar strategy for edible crab where starved crabs explored the entire temperature gradient during night (likely in search of food), but returned to the preferred temperature zone to reduce physiological stress during daytime. To confirm this, future work should investigate whether this nocturnal exploration of the gradient is reduced in fed crabs, or if thermal behaviour is unaffected by nutritional status, such as shown with red king crab (Christiansen et al. 2015).

The upper critical temperature (CTmax) in edible crab acclimated to winter temperature $\left(8^{\circ} \mathrm{C}\right.$ ) is about $22^{\circ} \mathrm{C}$ (Cuculescu et al., 1998). Given a lower critical temperature (CTmin) of about $\sim 1.3^{\circ} \mathrm{C}$ (our study), this suggest a thermal tolerance range of about $21^{\circ} \mathrm{C}\left(\sim 30 \Delta^{\circ} \mathrm{C}\right.$ if considering CTmax of warmacclimated crabs $\left(\sim 31^{\circ} \mathrm{C}\right)$, Cuculescu et al. 1998). In Norwegian waters, the edible crab seldom meets CTmax and CTmin (Table 2). In a recent review, Pörtner (2017) emphasized the need to consider non-critical thresholds, like Pejus temperatures, when determining the thermal performance of a species. For edible crab the upper Pejus temperature was $\sim 15-16^{\circ} \mathrm{C}$ for animals acclimated in the laboratory at $10^{\circ} \mathrm{C}$ (Metzger et al. 2007). Further support is found in studies on the temperature effect on neural responses in limbs of edible crab. Both Pearson et al. (1999) (working on edible crabs acclimated to $8^{\circ} \mathrm{C}$ in the lab) and Hyde et al. (2015) (using edible crabs collected during the winter), found the highest excitatory junction potential (EJP) between 6 and $15^{\circ} \mathrm{C}$, with a rapid decline in EJP above $15^{\circ} \mathrm{C}$. In the experiment by Pearson et al. (1999) there was also a drop in EJP from 6 to $5^{\circ} \mathrm{C}$, indicating that a lower Pejus temperature for winter acclimated edible crabs might be in this range. This is further supported in field studies by Karlsson and Christiansen (1996) who observed that temperatures below $5{ }^{\circ} \mathrm{C}$ appeared to limit the vertical migration of edible crab in the intertidal zone. Thus, a functional thermal range for female edible crab appears to be in the range $5-16^{\circ} \mathrm{C}$, likely with an optimum around $13^{\circ} \mathrm{C}$ (Table 3). In context of the species natural thermal environment, it is apparent that, even though the temperatures experienced are far from critical, the thermal window matching preferred temperatures shrinks rapidly at higher latitude (Table 2). It is thus clear that northern crabs spend most the time in suboptimal conditions and that low temperatures, especially during the winter months, are likely to impede physiological performance and limit northward dispersal. The distribution of marine crustaceans is also shaped by the seasonal temperatures required to sustain basic life history processes (Hall and Thatje 2009; Levinton and Mackie 2013). The narrow thermal window of warmer seawater during summer and autumn months is critical for edible crab, as this is the main period for moulting, mating and subsequent energy acquisition (Williamson 1900; Edwards 1967; Edwards 1979; Bennett 1995; Tallack 2007; Bakke et al. 2018). Given the temperature effect on these processes (Cossins and Bowler 1987), and the positive relationship between thermal preference and optimal growth (Jobling 1981), it is likely that any further expansion of the realized habitat of edible crab will highly depend on the rate and magnitude of ocean warming and the concomitant temperature rise in shallow water in summer.

Large crustaceans are often key species in benthic communities, and their abundance can be important in regulating trophic structures of marine ecosystems (Boudreau and Worm 2012). The edible crab is an opportunistic forager, feeding on both soft and hard bottom fauna (Shelton et al. 1979; Lawton 1989; Hall et al. 1991). It is therefore likely that the species will have a significant impact on the ecosystem as it expands its distribution northward. For instance, Fagerli et al. (2014) suggested that the return of kelp forests in central Norway might be due to the increased abundance of edible crab in these areas, in that the crab prey on and reduce the number of grazing sea urchins. Future studies should therefore monitor the ecological impact of this northward migrating species.

It should be emphasized that our study was conducted on adult female crabs only, and that flexibility in thermal performance and tolerance can vary across ontogeny (Pörtner and Peck 2011). In an ecological context it is therefore important to consider the effects of temperature change on all life stages (Sinclair et al. 2016). Whether thermal adjustments occur during different life stages of edible crab should therefore be investigated, especially considering that juvenile crabs occupy the shallow sub-tidal to intertidal zone (Williamson 1900; Bennett 1995), where they are exposed to larger seasonal and diurnal fluctuations in ambient temperature. Thermal preference and tolerance should also be investigated in male crabs, which are less motile (Bennett and Brown 1983; Karlsson and Christiansen 1996) and which possibly form local populations in some areas (McKeown et al. 2017). Finally, the effect of temperature on the earliest life stages of this species should be investigated. Given the relatively high optimal developmental temperatures for laboratory reared larva (around $14^{\circ} \mathrm{C}$, Weiss et al. 2009), and the relatively low surface water temperatures in northern Norway (Table 2), it is likely that larval development is strongly impeded in the northern part of the crabs' distribution. Temperature studies on the offspring of northern crabs might help to determine if the increased abundance in the north is due to a higher survival of larvae in warmer waters (Lindley and Kirby 2010), or if larvae are adapted to lower temperatures, such as suggested for American lobster (Homarus americanus) (Quinn et al. 2013). 


\section{ACKNOWLEDGEMENTS}

This study was part of a $\mathrm{PhD}$ (S.B.) project on the biology and eco-physiology of edible crab Cancer pagurus, and was supported by internal funds at Møreforsking AS.

\section{REFERENCES}

Aldrich JC. 1975. Individual variability in oxygen consumption rates of fed and starved Cancer pagurus and Maia squinado. Comparative Biochemistry and Physiology, Part A: Physiology. 51, 175-183. doi: 10.1016/0300-9629(75)90433-8

Allison EH, Perry AL, Badjeck M-C, Adger WN, Brown K, Conway D, Halls AS, Pilling GM, Reynolds JD, Andrew NL, and Dulvy NK. 2009. Vulnerability of national economies to the impacts of climate change on fisheries. Fish and Fisheries. 10, 173-196. doi: 10.1111/j.1467-2979.2008.00310.x

Angilletta MJ. 2009. Thermal adaptation: A theoretical and empirical synthesis, Oxford University Press, Oxford.

Angilletta MJ, Niewiarowski PH and Navas CA. 2002. The evolution of thermal physiology in ectotherms. Journal of Thermal Biology. 27, 249-268. doi: 10.1016/S0306-4565(01)00094-8

Ansell AD. 1973. Changes in oxygen consumption, heart rate and ventilation accompanying starvation in the decapod crustacean Cancer pagurus. Netherlands Journal of Sea Research. 7, 455475. doi: 10.1016/0077-7579(73)90066-5

Bakke S, Wiech M, Pan M and Søvik G. 2016. Taskekrabbe i Troms. Fangstpotensiale, fangstsammensetning og kvalitet. Møreforsking, MA16-06. 29 pp.

Bakke S, Larssen WE, Woll AK, Søvik G, Gundersen AC, Hvingel C and Nilssen EM. 2018. Size at maturity and molting probability across latitude in female Cancer pagurus. Fisheries Research. 205, 43-51. doi: 10.1016/j.fishres.2018.03.024

Bennett DB. 1995. Factors in the life history of the edible crab (Cancer pagurus L.) that influence modelling and management. ICES marine science symposia. International Council for the Exploration of the Sea, Copenhagen.

Bennett DB and Brown CG. 1983. Crab (Cancer pagurus) migrations in the English Channel. Journal of the Marine Biological Association of the United Kingdom. 63, 371-398. doi: 10.1017/S0025315400070740

Boudreau SA and Worm B. 2012. Ecological role of large benthic decapods in marine ecosystems: a review. Marine Ecology Progress Series. 469, 195-213. doi: 10.3354/meps09862

Brattegard T. 2011. Endringer i norsk marin bunnfauna 1997-2010. DN-utredning 8-2011. $112 \mathrm{pp}$

Cerqueira M, Rey S, Silva T, Featherstone Z, Crumlish M and MacKenzie S. 2016. Thermal preference predicts animal personality in Nile tilapia Oreochromis niloticus. Journal of Animal Ecology. 85, 1389-1400. doi: 10.1111/1365-2656.12555

Cheung WWL, Lam VWY, Sarmiento JL, Kearney K, Watson $\mathrm{R}$ and Pauly D. 2009. Projecting global marine biodiversity impacts under climate change scenarios. Fish and Fisheries. 10, 235-251. doi: 10.1111/j.1467-2979.2008.00315.x

Cheung WWL, Lam VWY, Sarmiento JL, Kearney K, Watson R, Zeller D and Pauly D. 2010. Large-scale redistribution of maximum fisheries catch potential in the global ocean under climate change. Global Change Biology. 16, 24-35. doi: 10.1111/j.1365-2486.2009.01995.x

Christiansen JS, Schurmann H and Karamushko LI. 1997. Thermal behaviour of polar fish: A brief survey and suggestions for research. Cybium. 21, 353-362.

Christiansen JS, Sparboe M, Sæther B-S and Siikavuopio SI. 2015. Thermal behaviour and the prospect spread of an invasive benthic top predator onto the Euro-Arctic shelves. Diversity and Distributions. 21, 1004-1013. doi: 10.1111/ddi.12321

Clark DS and Green JM. 1991. Seasonal variation in temperature preference of juvenile Atlantic cod (Gadus morhua), with evidence supporting an energetic basis for their diel vertical migration. Canadian Journal of Zoology. 69, 1302-1307. doi: $10.1139 / \mathrm{z} 91-183$

Clark HL and Backwell PRY. 2016. Micro-climate and incubation in a fiddler crab species. Journal of Experimental Marine Biology and Ecology. 485, 18-23. doi: 10.1016/j.jembe.2016.08.009

Cossins AR and Bowler K. 1987. Temperature biology of animals, Chapman and Hall, London.

Crossin GT, Al-Ayoub SA, Jury SH, Howell WH and Watson WH. 1998. Behavioral thermoregulation in the American lobster Homarus americanus. Journal of Experimental Biology. 201, 365-374.

Cuculescu M, Hyde D and Bowler K. 1998. Thermal tolerance of two species of marine crab, Cancer pagurus and Carcinus maenas. Journal of Thermal Biology. 23, 107-110. doi: 10.1016/ S0306-4565(98)00008-4

Cumillaf JP, Blanc J, Paschke K, Gebauer P, Diaz F, Re D, Chimal ME, Vasquez J and Rosas C. 2016. Thermal biology of the sub-polar-temperate estuarine crab Hemigrapsus crenulatus (Crustacea: Decapoda: Varunidae). Biology Open. 5, 220-228. doi: $10.1242 /$ bio. 013516

Curtis DL and McGaw IJ. 2012. Salinity and thermal preference of Dungeness crabs in the lab and in the field: Effects of food availability and starvation. Journal of Experimental Marine Biology and Ecology. 413, 113-120. doi: 10.1016/j. jembe.2011.12.005

Despatie SP, Castonguay M, Chabot D and Audet C. 2001. Final Thermal Preferendum of Atlantic Cod: Effect of Food Ration. Transactions of the American Fisheries Society. 130, 263-275. doi: 10.1577/1548-8659(2001)130<0263:FTPOAC >2.0.CO;2

Edwards, E., 1967. The Yorkshire crab stocks. Laboratory leaflet (new series) no. $17.34 \mathrm{pp}$.

Edwards E. 1979. The edible crab and its fishery in British waters, The Buckland Foundation, Farnham Surrey, England.

Fagerli C, Norderhaug K, Christie H, Pedersen M and Fredriksen S. 2014. Predators of the destructive sea urchin Strongylocentrotus droebachiensis on the Norwegian coast. Marine Ecology Progress Series. 502, 207-218. doi: 10.3354/meps10701

FAO. 2015. FAO Fisheries \& Aquaculture - Species Fact Sheets Cancer pagurus (Linnaeus, 1758). http://www.fao.org/fishery/ species/2627/en (accessed 19. January 2019).

Faulkner KT, Clusella-Trullas S, Peck LS and Chown SL. 2014. Lack of coherence in the warming responses of marine crustaceans. Functional Ecology. 28, 895-903. doi: 10.1111/1365-2435.12219

Fox HM. 1936. The activity and metabolism of poikilothermal animals in different latitudes.-I. Proceedings of the Zoological Society of London. 106, 945-955. doi: 10.1111/j.1469-7998.1936. tb06295.x 
Fox HM and Wingfield CA. 1937. The activity and metabolism of poikilothermal animals in different latitudes.-II. Proceedings of the Zoological Society of London. A107, 275-282. doi: 10.1111/j.1096-3642.1937.tb00810.x

Fry FEJ. 1947. Effects of the environment on animal activity. Publications of the Ontario fisheries research laboratory no. 68. University of Toront Press, pp. 1-62.

Gaitán-Espitia JD, Bacigalupe LD, Opitz T, Lagos NA, Timmermann T and Lardies MA. 2014. Geographic variation in thermal physiological performance of the intertidal crab Petrolisthes violaceus along a latitudinal gradient. Journal of Experimental Biology. 217, 4379-4386. doi: 10.1242/jeb.108217

Haig JA, Bakke S, Bell MC, Bloor ISM, Cohen M, Coleman M, Dignan S, Kaiser MJ, Pantin JR, Roach M, Salomonsen H and Tully O. 2016. Reproductive traits and factors affecting the size at maturity of Cancer pagurus across Northern Europe. ICES Journal of Marine Science. 73, 2572-2585. doi: 10.1093/icesjms/ fsw081

Hall S and Thatje S. 2009. Global bottlenecks in the distribution of marine Crustacea: temperature constraints in the family Lithodidae. Journal of Biogeography. 36, 2125-2135. doi: 10.1111/j.1365-2699.2009.02153.x

Hall S, Basford D, Robertson M, Raffaelli D and Tuck I. 1991. Patterns of recolonisation and the importance of pit-digging by the crab Cancer pagurus in a subtidal sand habitat. Marine Ecology Progress Series. 72, 93-102.

Haro A. 1991. Thermal preferenda and behavior of Atlantic eels (genus Anguilla) in relation to their spawning migration. Environmental Biology of Fishes. 31, 171-184. doi: 10.1007/ BF00001018

Hunter E, Eaton D, Stewart C, Lawler A and Smith MT. 2013. Edible crabs "Go West": migrations and incubation cycle of Cancer pagurus revealed by electronic tags. PLoS ONE. 8. doi: 10.1371/journal.pone.0063991

Hyde D, Pearson T, Qari S and Bowler K. 2015. Adaptive considerations of temperature dependence of neuromuscular function in two species of summer- and winter-caught crab (Carcinus maenas and Cancer pagurus). Journal of Comparative Physiology, B. 185, 1-8. doi: 10.1007/s00360-015-0912-X

Jobling M. 1981. Temperature tolerance and the final preferendum-rapid methods for the assessment of optimum growth temperatures. Journal of Fish Biology. 19, 439-455. doi: 10.1111/j.1095-8649.1981.tb05847.x

Karlsson K and Christiansen MF. 1996. Occurrence and population composition of the edible crab (Cancer pagurus) on rocky shores of an islet on the south coast of Norway. Sarsia. 81, 307-314. doi: 10.1080/00364827.1996.10413628

Kelly MW, Sanford E and Grosberg RK. 2012. Limited potential for adaptation to climate change in a broadly distributed marine crustacean. Proceedings of the Royal Society B: Biological Sciences. 279, 349-356. doi: 10.1098/rspb.2011.0542

Kerr KA, Christy JH, Collin R and Guichard F. 2012. Reducing error in reproductive timing caused by temperature variation: interspecific differences in behavioural adjustment by fiddler crabs. Marine Ecology Progress Series. 459, 1-16. doi: 10.3354/ meps09832

Konecki JT, Woody CA and Quinn TP. 1995. Temperature preference in two populations of juvenile coho salmon, Oncorhynchus kisutch. Environmental Biology of Fishes. 44,
417-421. doi: 10.1007/bf00008256

Lafrance P, Castonguay M, Chabot D and Audet C. 2005. Ontogenetic changes in temperature preference of Atlantic cod. Journal of Fish Biology. 66, 553-567. doi: 10.1111/j.00221112.2005.00623.x

Lagerspetz KY and Vainio LA. 2006. Thermal behaviour of crustaceans. Biological Reviews. 81, 237-258. doi: 10.1017/ S1464793105006998

Lagerspetz KYH and Bowler K. 1993. Variation in heat tolerance in individual Asellus aquaticus during thermal acclimation. Journal of Thermal Biology. 18, 137-143. doi: 10.1016/03064565(93)90027-Q

Latrouite D and Noël P. 1993. Observations sur la maturité sexuelle et la ponte du tourteau Cancer pagurus en Manche. ICES Shellfish Committee, CM 1993/K:23. 4 pp

Lawton P. 1989. Predatory interaction between the brachyuran crab Cancer pagurus and decapod crustacean prey. Marine Ecology Progress Series. 52, 169-179. doi: 10.3354/meps052169

Le Foll A. 1986. Contribution a l'etude de la biologie du crabetourteau Cancer pagurus sur les cotes de Bretagne sud. Revue des Travaux de l'Institut des Peches Maritimes. 48, 5-22.

Levinton J and Mackie J. 2013. Latitudinal diversity relationships of fiddler crabs: biogeographic differences united by temperature. Global Ecology and Biogeography. 22, 1050-1059. doi: 10.1111/ geb.12064

Lewis L and Ayers J. 2014. Temperature preference and acclimation in the Jonah crab, Cancer borealis. Journal of Experimental Marine Biology and Ecology. 455, 7-13. doi: 10.1016/j.jembe.2014.02.013

Lindley JA and Kirby RR. 2010. Climate-induced changes in the North Sea Decapoda over the last 60 years. Climate Research. 42, 257. doi: $10.3354 / \mathrm{cr} 00917$

McCauley RW and Huggins NW. 1979. Ontogenetic and nonthermal seasonal effects on thermal preferenda of fish. American Zoologist. 19, 267-271. doi: 10.1093/icb/19.1.267

McKeown NJ, Hauser L and Shaw PW. 2017. Microsatellite genotyping of brown crab Cancer pagurus reveals fine scale selection and non-chaotic genetic patchiness within a high gene flow system. Marine Ecology Progress Series. 566, 91-103. doi: $10.3354 /$ meps 12044

Meek A. 1914. Migrations of the crab. Report of the Dove Marine Laboratory, Cullercoats, Northumberland. 3. 73-76 pp

Metzger R, Sartoris F, Langenbuch M and Portner H. 2007. Influence of elevated $\mathrm{CO} 2$ concentrations on thermal tolerance of the edible crab Cancer pagurus. Journal of Thermal Biology. 32, 144-151. doi: 10.1016/j.jtherbio.2007.01.010

Nielsen TV and McGaw IJ. 2016. Behavioral thermoregulation and trade-offs in juvenile lobster Homarus americanus. Biological Bulletin. 230, 35-50. doi: 10.1086/BBLv230n1p35

Padilla-Ramírez S, Díaz F, Re AD, Galindo-Sanchez CE, SanchezLizarraga AL, Nuñez-Moreno LA, Moreno-Sierra D, Paschke $\mathrm{K}$ and Rosas C. 2015. The effects of thermal acclimation on the behavior, thermal tolerance, and respiratory metabolism in a crab inhabiting a wide range of thermal habitats (Cancer antennarius, Stimpson, 1856, the red shore crab). Marine and Freshwater Behaviour and Physiology. 48, 89-101. doi: 10.1080/10236244.2015.1019212

Pearson J. 1908. Cancer, Williams and Norgate, London. Pearson T, Hyde D and Bowler K. 1999. Heterologous acclimation: 
a novel approach to the study of thermal acclimation in the crab Cancer pagurus. American Journal of Physiology: Regulatory, Integrative and Comparative Physiology. 277, R24-R30. doi: 10.1152/ajpregu.1999.277.1.R24

Perry AL, Low PJ, Ellis JR and Reynolds JD. 2005. Climate change and distribution shifts in marine fishes. Science. 308, 1912-1915. doi: 10.1126/science.1111322

Poloczanska ES, Brown CJ, Sydeman WJ, Kiessling W, Schoeman DS, Moore PJ, Brander K, Bruno JF, Buckley LB, Burrows MT, Duarte CM, Halpern BS, Holding J, Kappel CV, O'Connor MI, Pandolfi JM, Parmesan C, Schwing F, Thompson SA and Richardson AJ. 2013. Global imprint of climate change on marine life. Nature Climate Change. 3, 919-925. doi: 10.1038/ nclimate1958

Pörtner H-O, Bock C and Mark FC. 2017. Oxygen- and capacitylimited thermal tolerance: bridging ecology and physiology. Journal of Experimental Biology. 220, 2685-2696. doi: 10.1242/ jeb. 134585

Pörtner HO and Peck MA. 2011. Effects of Climate Change. in: Farrell, AP (Ed.). Encyclopedia of Fish Physiology. Academic Press, San Diego, pp. 1738-1745.

Pörtner HO and Gutt J. 2016. Impacts of climate variability and change on (marine) animals: Physiological underpinnings and evolutionary consequences. Integrative and Comparative Biology. 56, 31-44. doi: 10.1093/icb/icw019

Quinn BK, Rochette R, Ouellet P and Sainte-Marie B. 2013. Effect of temperature on development rate of larvae from cold-water American lobster (Homarus americanus). Journal of Crustacean Biology. 33, 527-536. doi: 10.1163/1937240X-00002150

Reiser S, Temming A, Hufnagl M, Eckhardt A and Herrmann J-P. 2016. Behavioral thermoregulation of the common brown shrimp (Crangon crangon, L.) throughout the seasonal cycle. Journal of Experimental Marine Biology and Ecology. 478, 1-9. doi: 10.1016/j.jembe.2016.01.017

Reynolds WW and Casterlin ME. 1979. Behavioral thermoregulation and the "final preferendum" paradigm. American Zoologist. 19, 211-224. doi: $10.1093 /$ icb/19.1.211

Roberts JL. 1957. Thermal acclimation of metabolism in the crab, Pachygrapsus crassipes Randall. II. Mechanisms and the influence of season and latitude. Physiological Zoology. 30, 242 255. doi: 10.1086/physzool.30.3.30160925

Robinson M and Tully O. 2000. Seasonal variation in community structure and recruitment of benthic decapods in a sub-tidal cobble habitat. Marine Ecology Progress Series. 206, 181-191. doi: $10.3354 /$ meps 206181

Sanford E and Kelly MW. 2011. Local adaptation in marine invertebrates. Annual Review of Marine Science. 3, 509-535. doi: 10.1146/annurev-marine-120709-142756

Schlaff AM, Heupel MR and Simpfendorfer CA. 2014. Influence of environmental factors on shark and ray movement, behaviour and habitat use: a review. Reviews in Fish Biology and Fisheries. 24, 1089-1103. doi: 10.1007/s11160-014-9364-8

Scott K, Harsanyi P and Lyndon AR. 2018. Baseline measurements of physiological and behavioural stress markers in the commercially important decapod Cancer pagurus (L.). Journal of Experimental Marine Biology and Ecology. 507, 1-7. doi: 10.1016/j.jembe.2018.07.001

Shelton RGJ, Kinnear JAM and Livingstone K. 1979. A preliminary account of the feeding habits of the edible crab, Cancer pagurus
L. off N. W. Scotland. C.M. 1979/K: 35. 6 pp.

Siikavuopio SI, Sæther B-S, Johnsen H, Evensen T and Knudsen R. 2014. Temperature preference of juvenile Arctic charr originating from different thermal environments. Aquatic Ecology. 48, 313-320. doi: 10.1007/s10452-014-9485-0

Sims DW, Wearmouth VJ, Southall EJ, Hill JM, Moore P, Rawlinson K, Hutchinson N, Budd GC, Righton D, Metcalfe JD, Nash JP and Morritt D. 2006. Hunt warm, rest cool: bioenergetic strategy underlying diel vertical migration of a benthic shark. Journal of Animal Ecology. 75, 176-190. doi: 10.1111/j.13652656.2005.01033.x

Sinclair BJ, Marshall KE, Sewell MA, Levesque DL, Willett CS, Slotsbo S, Dong Y, Harley CDG, Marshall DJ, Helmuth BS, Huey RB and Vasseur D. 2016. Can we predict ectotherm responses to climate change using thermal performance curves and body temperatures? Ecology Letters. doi: 10.1111/ele.12686

Skajaa K, Fernö A, Løkkeborg S and Haugland EK. 1998. Basic movement pattern and chemo-oriented search towards baited pots in edible crab (Cancer pagurus L.). Hydrobiologia. 371/372, 143-153. doi: 10.1007/978-94-011-5090-3 18

Somero GN. 2012. The Physiology of Global Change: Linking Patterns to Mechanisms. Annual Review of Marine Science. 4, 39-61. doi: 10.1146/annurev-marine-120710-100935

Sonia R, Nikoletta D and Simon M. 2015. Animal personality relates to thermal preference in wild-type zebrafish, Danio rerio. Zebrafish. 12, 243-249. doi: 10.1089/zeb.2014.1076

Stillman JH. 2003. Acclimation capacity underlies susceptibility to climate change. Science. 301, 65-65. doi: 10.1126/ science. 1083073

Stillman JH. 2004. A comparative analysis of plasticity of thermal limits in porcelain crabs across latitudinal and intertidal zone clines. International Congress Series. 1275, 267-274. doi: 10.1016/j.ics.2004.09.034

Stillman JH and Somero GN. 2000. A comparative analysis of the upper thermal tolerance limits of eastern Pacific Porcelain crabs, Genus Petrolisthes: Influences of latitude, vertical zonation, acclimation, and Phylogeny. Physiological and Biochemical Zoology. 73, 200-208. doi: 10.1086/316738

Søvik G, Jenssen M, Hjelset AM and Krogness C. 2017. Ressursundersøkelseav taskekrabbelangsnorskekysten-Rapport fra fangstregistreringer i 2001-2015. Havforskingsinstituttet, Nr. 25-2017. 14 pp.

Tallack SML. 2007. The reproductive cycle and size at maturity observed in Cancer pagurus in the Shetland Islands, Scotland. Journal of the Marine Biological Association of the United Kingdom. 87, 1181-1189. doi: 10.1017/S0025315407054094

Tashian RE. 1956. Geographic variation in the respiratory metabolism and temperature coefficient in tropical and temperate forms of the fiddler crab, Uca pugnax. Zoologica. 41, 39-47.

Torheim S. 1977. Krabbeundersøkelser på Nordlandskysten i 1976. Fisken og Havet. 1, 9-13.

Torheim S. 1979. Krabbeundersøkelser på Nordlandskysten i 1978. Fisken og Havet. 2, 77-79.

Ungfors A. 2007. Sexual maturity of the edible crab (Cancer pagurus) in the Skagerrak and the Kattegat, based on reproductive and morphometric characters. ICES Journal of Marine Science: Journal du Conseil. 64, 318-327. doi: 10.1093/ icesjms/fs1039 
Ungfors A, Hallbäck H and Nilsson PG. 2007. Movement of adult edible crab (Cancer pagurus L.) at the Swedish West Coast by mark-recapture and acoustic tracking. Fisheries Research. 84, 345-357. doi: 10.1016/j.fishres.2006.11.031

Vernbergs WB and Vernberg FJ. 1966. Studies on the physiological variation between tropical and temperate zone fiddler crabs of the genus Uca-V. Effect of temperature on tissue respiration. Comparative Biochemistry and Physiology. 17, 363-374. doi: 10.1016/0010-406X(66)90574-3

Wagner CP and Wahl DH. 2007. Evaluation of temperatureselection differences among juvenile muskellunge originating from different latitudes. The Muskellunge Symposium: A Memorial Tribute to E.J. Crossman. Developments in environmental biology of fishes 26. Springer Netherlands, Dordrecht, pp. 85-98.

Weiss M, Thatje S, Heilmayer O, Anger K, Brey T and Keller M. 2009. Influence of temperature on the larval development of the edible crab, Cancer pagurus. Journal of the Marine Biological Association of the United Kingdom. 89, 753-759. doi: 10.1017/ S0025315409003269

Williamson HC. 1900. Contributions to the life-history of the edible crab (Cancer pagurus, Linn.). Eighteenth annual report of the Fishery Board for Scotland. Glasgow, pp. 77-143.

Williamson HC. 1904. Contribution to the life-histories of the edible crab (Cancer pagurus) and of orther decapod crustacea: Impregnation; spawning; casting; distribution; rate of growth. Twenty-second annual report of the Fishery Board for Scotland. Glasgow, pp. 100-140.

Woll A. 2003. In situ observations of ovigerous Cancer pagurus Linnaeus, 1758 in Norwegian waters (Brachyura, Cancridae). Crustaceana. 76, 469-478. doi: 10.1163/156854003322033861

Woll AK, van der Meeren GI and Fossen I. 2006. Spatial variation in abundance and catch composition of Cancer pagurus in Norwegian waters: biological reasoning and implications for assessment. ICES Journal of Marine Science: Journal du Conseil. 63, 421-433. doi: 10.1016/j.icesjms.2005.10.004

Editorial responsibility: Anne Helene Tandberg.

This article is open-access and distributed under the terms of the Creative Commons Attribution 4.0 International license. This permits all non-commercial use, distribution, and reproduction in any medium, provided the original work is properly cited.

(http://creativecommons.org/licenses/by/4.0/). 